\title{
Pengaruh Motivasi, Kompetensi dan Kemampuan Finansial Terhadap Minat Melanjutkan Studi Pada Dosen di Universitas Tridinanti Palembang
}

\author{
Liliana $^{1)}$, Veny Mayasari ${ }^{2)}$ \\ ${ }^{1), 2)}$ Program Studi Manajemen Universitas Tridinanti Palembang \\ Jalan Kapten Marzuki No. 2446 Kamboja Palembang Kode Pos 30129 \\ Email: liliana.ishak@yahoo.com ${ }^{1)}$,veny_mayasari@univ-tridinanti.ac.id ${ }^{2}$
}

\begin{abstract}
This research aims to know the influence of motivation, competence and financial capability toward interest continue studies on lecturer at the University of Tridinanti Palembang. This type of research is associative with the quantitative approach. The type of the data being used is the primary data by the method of data collection the questionnaire, interview and observation. The population in this research is still a qualified lecturer throughout the master's degree at the University of Tridinanti Palembang totaling 178 people. Sampling techniques using accidental sampling by the number of samples was determined as many as 100 respondents. The results showed that the hypothesis test simultaneously motivation, competence and the ability to financially influential interest continue studies on lecturer at University of Tridinanti Palembang with the value significance of 0.000 . While partially, motivation, competence and financial capability to interest in continue study with each influence quantity amounting to 37\%, 32\%, and $23 \%$.
\end{abstract}

Keywords: Motivation, Competence, Financial Capability, Interest.

\begin{abstract}
ABSTRAK
Penelitian ini bertujuan untuk mengetahui pengaruh motivasi, kompetensi dan kemampuan finansial terhadap minat melanjutkan studi pada dosen di Universitas Tridinanti Palembang. Jenis penelitian ini adalah asosiatif dengan pendekatan kuantitatif. Jenis data yang digunakan adalah data primer dengan teknik pengumpulan data kuesioner, wawancara dan observasi. Populasi pada penelitian ini adalah seluruh dosen tetap yang berkualifikasi magister di Universitas Tridinanti Palembang yang berjumlah 178 orang. Teknik pengambilan sampel menggunakan accidental sampling dengan jumlah sampel ditentukan sebanyak 100 responden. Hasil uji hipotesis menunjukkan bahwa secara simultan motivasi, kompetensi dan kemampuan finansial berpengaruh signifikan terhadap minat melanjutkan studi pada dosen di Universitas Tridinanti Palembang dengan nilai signifikansi sebesar 0,000. Sedangkan secara parsial, motivasi, kompetensi dan kemampuan finansial berpengaruh terhadap minat melanjutkan studi dengan besaran pengaruh masing-masing sebesar $37 \%$, $32 \%$ dan $23 \%$.
\end{abstract}

Kata kunci: Motivasi; Kompetensi; Kemampuan Finansial; Minat. 


\section{Pendahuluan}

Salah satu indikator keberhasilan proses pendidikan tinggi di suatu negara dapat diukur dari seberapa baik kualitas tenaga pendidik di negara tersebut. Dosen adalah pendidik profesional dan ilmuwan dengan tugas utama mentrasformasikan, mengembangkan dan menyebarluaskan ilmu pengetahuan dan teknologi melalui Tridarma perguruan tinggi. Untuk dapat menjalankan kewajiban tridharma perguran tinggi dengan baik, seorang dosen dituntut untuk memiliki kualifikasi akademik yang baik untuk mendukung pelaksanaan tugas-tugas tersebut.

Kualifikasi akademik erat kaitannya dengan latar belakang pendidikan seseorang. Di Indonesia mayoritas dosen masih berkualifikasi akademik strata dua (magister), kualifikasi yang merupakan kualifikasi akademik minimal untuk menjadi dosen.

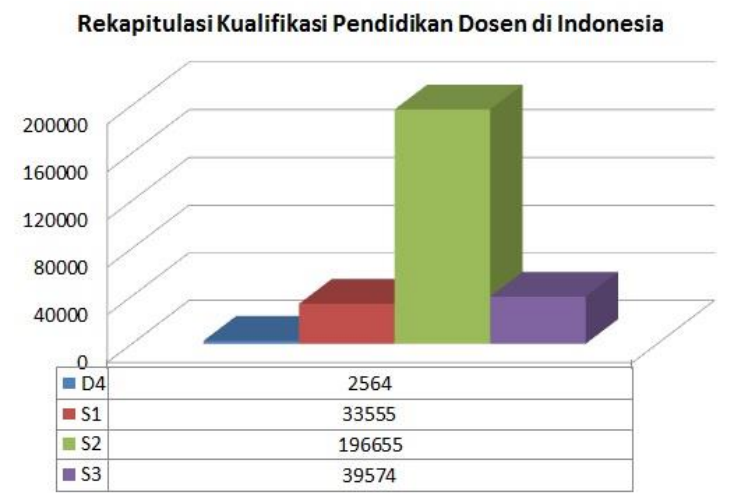

Sumber : Forlap Dikti (2018)

Gambar 1. Rekapitulasi Pendidikan Dosen di Indonesia

Berbagai cara dilakukan oleh pemerintah untuk meningkatkan kualifikasi akademik dosen di Indonesia diantaranya dengan menyediakan berbagai skim beasiswa doktoral yaitu BUDI DN, BUDI LN, maupun BPPDN. Namun meskipun telah menyediakan berbagai skema pemberian beasiswa, minat dosen untuk melanjutkan pendidikan masih belum optimal.

Jika diperhatikan lebih mendalam lagi, masalah rendahnya minat dosen untuk melanjutkan studi ke jenjang pendidikan yang lebih tinggi (Strata 3) tidak hanya menjadi masalah nasional, tapi lebih spesifik lagi menjadi masalah setiap perguruan tinggi terutama perguruan tinggi swasta di Indonesia. Salah satu perguruan tinggi yang memiliki masalah pada rendahnya jumlah dosen yang berstrata tiga adalah Universitas Tridinanti Palembang, dimana rasio dosen yang memiliki kualifikasi akademik doktor atau yang lebih tinggi hanya mencapai 7,93\% dibandingkan total dosen.

Beberapa faktor yang sangat mungkin menjadi penyebab rendahnya minat dosen di Indonesia maupun di Universitas Tridinanti Palembang untuk melanjutkan studi doktor berdasarkan hasil observasi penulis yang pertama adalah besarnya dana yang harus dikeluarakan. Ketika seorang dosen memutuskan untuk melanjutkan studi, hal yang pertama yang harus dihadapi adalah dana pendidikan. Di Sumatera khususnya Sumatera Selatan besaran dana pendidikan doktor mencapai 15-20 juta per semester. Biaya ini belum termasuk biaya lain-lain seperti biaya pembelian buku (pustaka), biaya pembangunan (jika perguruan tinggi tujuan belum menerapkan uang kuliah tunggal) serta biaya lainnya. Disisi lain pendapatan dosen berpotensi berkurang ketika akan melanjutkan studi dikarenakan aturan yang mengharuskan dosen yang studi lanjut harus berstatus izin belajar atau tugas belajar.

Faktor kedua yang mungkin menyebabkan rendahnya minat dosen untuk melanjutkan studi adalah motivasi. Tidak sedikit dosen yang memiliki kemampuan finansial untuk melanjutkan studi namun tidak termotivasi untuk melanjutkan studi dengan berbagai alasan seperti faktor usia yang dinilai sudah tidak muda lagi.

Selain itu berbagai faktor lainnya yang juga disinyalir menjadi penyebab rendahnya minat dosen di Universitas Tridinanti untuk melanjutkan studi seperti yang berhubungan dengan kompetensi dimana masih terdapat beberapa dosen yang kurang memiliki keyakinan akan kompetensi dirinya sehingga tidak memiliki cukup keberanian untuk mendaftarkan diri untuk melanjutkan pendidikan baik itu melalui jalur beasiswa maupun non beasiswa.

Berbagai upaya telah dilakukan oleh pemerintah umumnya dan lembaga pendidikan swasta seperti Universitas Tridinanti Palembang khususnya untuk meningkatkan minat dosen melanjutkan studi seperti pemberian berbagai skema beasiswa oleh pemerintah maupun bantuan dana dari Yayasan Pendidikan Nasional Tridinanti sebagai yayasan yang menaungi Universitas Tridinanti, namun fakta di lapangan menunjukkan bahwa minat dosen untuk melanjutkan studi tidak mengalami peningkatan yang cukup signifikan bahkan dapat dikatakan rendah.

Minat dapat diartikan sebagai aspek psikis manusia yang dapat mendorong untuk mencapai tujuan. Sangat sedikit penelitian terdahulu yang membahas mengenai faktor-faktor yang mempengaruhi minat khususnya minat dosen untuk melanjutkan studi. Beberapa kajian terdahulu yang membahas tentang minat pernah dilakukan oleh Kusuma (2009) yang menganalisis pengaruh kompetensi terhadap minat dan menemukan bahwa kompetensi berpengaruh terhadap minat. Azizah (2015) menemukan bahwa kemampuan finansial berpengaruh terhadap minat sedangkan Seto (2017) dan Nurhayani (2012) menemukan bahwa motivasi berpengaruh terhadap minat.

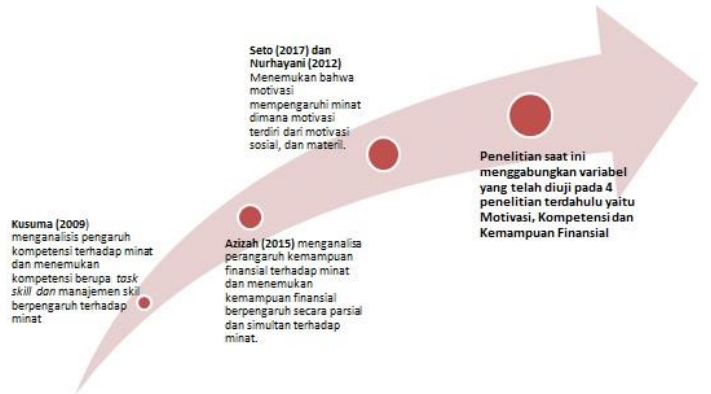

Sumber : Diolah Penulis (2019)

Gambar 2. Road Map Penelitian 
Namun belum terdapat penelitian terdahulu yang secara spesifik meneliti tentang minat melanjutkan studi pada profesi dosen. Hal inilah yang menjadi kebaruan (novelty) pada penelitian ini.

\section{A. Minat}

Minat adalah kesadaran individu terhadap sesuatu hal yang bersangkut paut dengan dorongan sehingga individu memusatkan seluruh perhatiannya terhadap objek tertentu dengan senang hati melakukan aktivitas yang berhubungan dengan objek (Crow \& Crow, 2003). Minat merupakan salah satu aspek psikis manusia yang dapat mendorong untuk mencapai tujuan. Seseorang yang memiliki minat terhadap suatu obyek, cenderung untuk memberikan perhatian atau merasa senang yang lebih besar kepada obyek tersebut. Namun apabila obyek tersebut tidak menimbulkan rasa senang, maka ia tidak akan memiliki minat pada obyek tersebut.

Menurut Crow \& Crow (2003) faktor-faktor yang mempengaruhi minat adalah:

1. Faktor dorongan dari dalam individu

Faktor ini muncul dari adanya kebutuhan-kebutuhan dasar individu, misalnya dorongan untuk mencari makan karena lapar.

2. Faktor motif sosial

Individu didorong untuk menyesuaikan diri dengan lingkungan agar dapat diterima dan diakui oleh lingkungan tersebut misalnya minat untuk mengenakan pakaian mahal dan bermerk.

3. Faktor emosional

Minat berkaitan dengan erat dengan perasaan atau emosi keberhasilan dalam suatu aktivitas memunculkan perasaan senang dan mendorong timbulnya minat untuk melakukan hal yang sama dikemudian hari. Dan kegagalan sering menyebabkan hilangnya minat.

Beberapa Peneliti telah banyak menguji beberapa variabel yang mempengaruhi minat diantaranya Nurhayani (2012) menyatakan bahwa motivasi sosial, motivasi karir dan motivasi ekonomi mempengaruhi minat. Kusuma (2009) mengungkapkan kompetensi menjadi salah satu faktor yang mempengaruhi minat sedangkan Azizah (2015) menyatakan bahwa kemampuan finansial berpengaruh baik secara parsial maupun simultan terhadap minat seseorang.

\section{B. Hubungan Motivasi Terhadap Minat}

Motivasi berasal dari kata motif (motive), yang berarti dorongan dengan demikian motivasi berarti suatu kondisi yang mendorong atau menjadi sebab seseorang melakukan suatu perbuatan/kegiatan yang berlangsung secara sadar (Bangun, 2018). Menurut Daft (2011) Motivasi dapat diartikan sebagai kekuatan yang muncul dalam diri ataupun dari luar diri seseorang dan membangkitkan semangat serta ketekunan untuk mencapai sesuatu yang diinginkan.

Menurut Notoadmodjo (2009) dalam diri manusia ada dua motivasi atau motif yaitu motif primer atau motif yang tidak dipelajari dan motif sekunder atau motif yang dipelajari melalui pengalaman serta interaksi dengan orang lain.

Menurut Daft (2011) Konsep motivasi dibedakan menjadi tiga motif yaitu :

1. Motif untuk berprestasi (Need for achievement)

Motif berprestasi adalah suatu dorongan yang ada pada setiap manusia untuk mencapai hasil kegiatannya atau hasil kerjanya secara maksimal. Indikator motivasi berprestasi adalah: berorientasi pada tujuan, menyukai pekerjaan menantang, bertanggung jawab, berani mengambil risiko, dan kreatif dan inovatif.

2. Motif untuk berafiliasi (Need for affiliation)

Motif untuk berafiliasi yaitu kebutuhan manusia sebagai makhluk sosial, oleh sebab itu manusia menjadi bermakna dalam interaksinya dengan manusia lain (sosial). Dengan demikian, secara naluri kebutuhan atau dorongan untuk berafiliasi dengan sesama manusia melekat pada setiap orang.

3. Motif untuk berkuasa (Need for power)

Motif untuk berkuasa yaitu motif dimana manusia mempunyai kecenderungan untuk mempengaruhi dan mempengaruhi orang lain, baik dalam kelompok sosial yang kecil maupun kelompok sosial.

Seto (2017) dan Nurhayani (2012) menemukan bahwa motivasi sosial, motivasi karir dan motivasi ekonomi mempengaruhi minat seseorang, sedangkan Ismail dan Lestari (2012) menemukan bahwa kualitas motivasi dan motivasi karir berpengaruh berpengaruh secara parsial dan simultan terhadap minat. Berdasarkan uraian tersebut maka dirumuskan hipotesis pertama sebagai berikut :

$\mathrm{H}_{1}$ : Terdapat pengaruh yang signifikan antara motivasi dan minat dosen melanjutkan studi pada dosen di Universitas Tridinanti Palembang.

\section{Hubungan Kompetensi Terhadap Minat}

Kompetensi oleh Spencer (2009) adalah karakteristik yang mendasari seseorang berkaitan dengan efektifitas kinerja individu dalam pekerjaannya atau karakteristik dasar individu yang memiliki hubungan kausal atau sebab-akibat dengan kriteria yang dijadikan acuan, efektif atau berkinerja prima atau superior di tempat kerja atau pada situasi tertentu.

Beberapa ahli mengutarakan gugus dan dimensi kompetensi. Menurut Spencer (2009) Secara rinci, ada 5 dimensi atau indikator kompetensi yang harus dimiliki oleh semua individu, yaitu :

a. Task skills, yaitu keterampilan untuk melaksanakan tugas-tugas rutin sesuai dengan standar ditempat kerja.

b. Task management skills, yaitu keterampilan untuk mengelola serangkaian tugas yang berbeda yang muncul dalam pekerjaan.

c. Contigency management skills, yaitu keterampilan mengambil tindakan yang cepat dan tepat bila timbul suatu masalah dalam pekerjaan.

d. Job role environment skills, yaitu keterampilan untuk bekerja sama serta memelihara kenyamanan lingkungan kerja. 
e. Transfer skill, yaitu keterampilan untuk beradaptasi dengan lingkungan kerja baru.

Tidak banyak penelitian yang meneliti pengaruh kompetensi terhadap minat. Salah satunya dilakukan oleh Kusuma (2009) yang menemukan bahwa kompetensi memiliki pengaruh yang positif dan signifikan terhadap minat meskipun bukan merupakan variabel yang paling berpengaruh diantara variabel lainnya.

Berdasarkan uraian diatas maka dirumuskan hipotesis kedua sebagai berikut :

$\mathrm{H}_{2}$ : Terdapat pengaruh yang signifikan antara kompetensi dan minat dosen melanjutkan studi pada dosen di Universitas Tridinanti Palembang.

\section{Hubungan Kemampuan Finansial Terhadap Minat}

Kemampuan adalah kapasitas seorang individu untuk melakukan beragam tugas dalam suatu pekerjaan. Kemampuan adalah sebuah penilaian terkini atas apa yang dapat dilakukan seseorang. (Azizah, 2015). Sedangkan kemampuan finansial adalah kemampuan seseorang untuk memecahkan persoalan keuangannya baik yang di dapat melalui pendapatan tetap maupun non tetap dalam menghadapi situasi ekonomi dimana suatu keadaan akan mempengaruhi minat seseorang dalam melakukan sesuatu.

Tidak banyak penelitian yang meneliti pengaruh kemampuan finansial terhadap minat, salah satunya penelitian yang dilakukan Azizah (2015) yang menemukan bahwa kemampuan finansial secara simultan berpengaruh terhadap minat dengan persentase sebesar 38,7\%. Berdasarkan uraian diatas maka dirumuskan hipotesis kedua sebagai berikut :

$\mathrm{H}_{3}$ : Terdapat pengaruh yang signifikan antara kompetensi dan minat dosen melanjutkan studi pada dosen di Universitas Tridinanti Palembang.

\section{E. Metodologi Penelitian}

1. Jenis Penelitian

Jenis penelitian ini adalah Asosiatif, yaitu penelitian yang bertujuan untuk mencari tahu pengaruh motivasi, kompetensi dan kemampuan finansial terhadap minat melanjutkan studi pada dosen di Universitas Tridinanti Palembang.

2. Populasi dan Sampel

Populasi dalam penelitian ini adalah semua dosen tetap yang berstrata dua (magister) di Universitas Tridinanti Palembang yang berjumlah 178 orang. Jenis Sampel yang digunakan adalah Accidental Sampling dengan jumlah sampel yang ditentukan sebanyak 100 responden.

3. Jenis Data dan Teknik Pengumpulan Data Jenis data yang digunakan adalah data kualitatif, Sumber data yang digunakan adalah data primer berupa kuesioner dan hasil wawancara dengan responden.

4. Definisi Operasional

Variabel yang digunakan dalam penelitian ini terdiri dari variabel independen yaitu motivasi, kompetensi dan kemampuan finansial dan satu variabel dependen yaitu minat melanjutkan studi. Variabel penelitian pada penelitian ini didefinisikan sebagai berikut :

a. Motivasi didefinisikan sebagai dorongan bagi seorang dosen untuk melakukan suatu usaha atau kegiatan dengan tujuan melanjutkan studi yang berlangsung secara sadar.

Motivasi diukur dengan menggunakan tiga indikator yaitu motivasi berprestasi, motivasi berafiliasi dan motivasi berkuasa.

b. Kompetensi didefinisikan sebagai karakteristik yang mendasari seorang dosen berkaitan dengan efektifitas kinerjanya yang berhubungan dengan minat melanjutkan studi. Kompetensi diukur dengan menggunakan indikator Task skills, Task management skills, Contigency management skills, Job role environment skills, Transfer skill

c. Kemampuan finansial didefinisikan sebagai Kemampuan seorang untuk memecahkan persoalan keuangannya baik yang di dapat melalui pendapatan tetap maupun non tetap dalam upaya melanjutkan studi. Kemampuan finansial diukur dengan menggunakan besaran pendapatan dan pengeluaran.

Masing-masing variabel diukur dengan 6 butir pernyataan dimana setiap pernyataan dinilai dengan menggunakan skala likert 5 point.

5. Model Analisis Data

Model analisis data yang digunakan dalam penelitian ini adalah analisis kuantitatif, dengan teknik analisis data kuantitatif. Teknik analisis data dimulai dengan melakukan :

a. Uji instrumen penelitian

Uji instrumen penelitian yang digunakan pada penelitian ini yaitu uji validitas dan uji realibilitas. Dengan kriteria penerimaan uji realibilitas apabila nilai cronbach $\alpha>0,60$. (Sugiyono, 2010). Sedangkan kriteria penerimaan untuk uji validitas adalah jika $r$ hitung $>r$ tabel (Ghozali,2005).

b. Uji Asumsi klasik

Uji Asumsi klasik yang digunakan pada penelitian ini meliputi uji multikolinearitas, heterokedasitas dan normalitas.

c. Uji Regresi Linier Berganda

Analisis regresi linier berganda digunakan untuk mengetahui ada tidaknya pengaruh motivasi, kompetensi dan kemampuan finansial terhadap minat melanjutkan studi pada dosen di Universitas Tridinanti Palembang. Model hubungan disusun dalam persamaan sebagai berikut:

$Y=b_{1} X_{1}+b_{2} X_{2}+b_{3} X_{3}+e$

Dimana :

$\mathrm{Y}=$ Minat melanjutkan studi

$\mathrm{b}=$ Koefisien regresi variabel $\mathrm{X}$

$\mathrm{X}_{1}=$ Motivasi

$\mathrm{X}_{2}=$ Kompetensi

$\mathrm{X}_{3}=$ Kemampuan finansial

$\mathrm{e}=$ error $/$ variabel pengganggu 
Dengan kriteria penerimaan sebagai berikut:

a. Jika Sig $\geq 0,05$ maka Ho diterima dan Ha ditolak yang artinya tidak terdapat pengaruh yang signifikan antara Motivasi, Kompetensi dan kemampuan finansial terhadap minat melanjutkan studi pada dosen di Universitas Tridinanti Palembang.

b. Jika Sig < 0,05 maka Ho ditolak dan Ha diterima yang artinya terdapat pengaruh yang signifikan antara Motivasi, Kompetensi dan kemampuan finansial terhadap minat melanjutkan studi pada dosen di Universitas Tridinanti Palembang.

\section{Pembahasan}

A. Deskripsi Karakteristik Responden

Deskripsi karakteristik responden adalah gambaran mengenai keberadaan responden. Berikut ini gambaran mengenai karakteristik responden pada penelitian ini:

Tabel 1. Karakteristik Responden

\begin{tabular}{|l|c|c|}
\hline \multicolumn{1}{|c|}{ Profil Responden } & Jumlah & Persentase \\
\hline Jenis Kelamin & & \\
$-\quad$ Laki-laki & 36 & $36 \%$ \\
$-\quad$ Perempuan & 64 & $64 \%$ \\
\hline Total & $\mathbf{1 0 0}$ & $\mathbf{1 0 0 \%}$ \\
\hline Fakultas & & \\
$-\quad$ Fak. Ekonomi & 72 & $72 \%$ \\
$-\quad$ Fak. Teknik & 20 & $20 \%$ \\
$-\quad$ FKIP & 8 & $8 \%$ \\
- Fak. Pertanian & 2 & $2 \%$ \\
\hline Total & $\mathbf{1 0 0}$ & $\mathbf{1 0 0 \%}$ \\
\hline Usia & & \\
- <30 Tahun & 21 & $21 \%$ \\
- 30-45 Tahun & 53 & $53 \%$ \\
- > 45-60 Tahun & 21 & $21 \%$ \\
- > 60 Tahun & 2 & $2 \%$ \\
\hline Total & $\mathbf{1 0 0}$ & $\mathbf{1 0 0 \%}$ \\
\hline Jabatan Akademik & & \\
- Tenaga Pengajar & 11 & $11 \%$ \\
- Asisten Ahli & 45 & $45 \%$ \\
- Lektor & 43 & $43 \%$ \\
- Lektor Kepala & 1 & $1 \%$ \\
\hline Total & $\mathbf{1 0 0}$ & $\mathbf{1 0 0 \%}$ \\
\hline Sal : &
\end{tabular}

Sumber : Hasil Pengolahan Data (2019)

Berdasarkan profil responden, dapat diketahui mayoritas responden pada penelitian ini berjenis kelamin adalah perempuan (64\%), mayoritas berasal dari fakultas ekonomi (72\%), berusia mayoritas $30-45 \%$ dan mayoritas memiliki jabatan akademik asisten ahli (45\%).

\section{B. Hasil Penelitian}

1. Hasil Uji Instrumen Penelitian

Uji instrumen pada penelitian ini menggunakan uji validitas dan uji realibilitas. Berikut ini hasil uji validitas dan realibilitas pada penelitian ini:
Tabel 2. Hasil Uji Validitas

\begin{tabular}{|c|c|c|c|}
\hline Variabel & Butir & r-hitung & Keterangan \\
\hline \multirow{6}{*}{$\begin{array}{l}\text { Motivasi } \\
\left(\mathrm{X}_{1}\right)\end{array}$} & 1 & 0,636 & Valid \\
\hline & 2 & 0,788 & Valid \\
\hline & 3 & 0,672 & Valid \\
\hline & 4 & 0,668 & Valid \\
\hline & 5 & 0,616 & Valid \\
\hline & 6 & 0,300 & Valid \\
\hline \multirow{6}{*}{$\begin{array}{l}\text { Kompetensi } \\
\left(\mathrm{X}_{2}\right)\end{array}$} & 1 & 0,780 & Valid \\
\hline & 2 & 0,748 & Valid \\
\hline & 3 & 0,769 & Valid \\
\hline & 4 & 0,746 & Valid \\
\hline & 5 & 0,829 & Valid \\
\hline & 6 & 0,623 & Valid \\
\hline \multirow{6}{*}{$\begin{array}{l}\text { Kemampuan } \\
\text { Finansial } \\
\left(\mathrm{X}_{3}\right)\end{array}$} & 1 & 0,834 & Valid \\
\hline & 2 & 0,659 & Valid \\
\hline & 3 & 0,790 & Valid \\
\hline & 4 & 0,596 & Valid \\
\hline & 5 & 0,798 & Valid \\
\hline & 6 & 0,268 & Valid \\
\hline \multirow{6}{*}{$\begin{array}{l}\text { Minat } \\
\text { Melanjutkan } \\
\text { Studi } \\
\text { (Y) }\end{array}$} & 1 & 0,740 & Valid \\
\hline & 2 & 0,845 & Valid \\
\hline & 3 & 0,754 & Valid \\
\hline & 4 & 0,617 & Valid \\
\hline & 5 & 0,741 & Valid \\
\hline & 6 & 0,614 & Valid \\
\hline
\end{tabular}

Sumber : Hasil Pengolahan Data (2019)

Berdasarkan hasil uji validitas, diketahui bahwa nilai r-hitung masing-masing variabel lebih besar dari r-tabel yang artinya semua butir instrumen penelitian valid.

Tabel 3. Hasil Uji Realibilitas

\begin{tabular}{|c|l|c|c|}
\hline No & \multicolumn{1}{|c|}{ Variabel } & $\begin{array}{c}\text { Cronbach } \\
\text { Alpha }\end{array}$ & Ket \\
\hline 1 & Motivasi $\left(\mathrm{X}_{1}\right)$ & 0,679 & Realibel \\
\hline 2 & Kompetensi $\left(\mathrm{X}_{2}\right)$ & 0,846 & Realibel \\
\hline 3 & $\begin{array}{l}\text { Kemampuan } \\
\text { Finansial }\left(\mathrm{X}_{3}\right)\end{array}$ & 0,768 & Realibel \\
\hline 4 & Minat $(\mathrm{Y})$ & 0,810 & Realibel \\
\hline
\end{tabular}

Sumber : Hasil Pengolahan Data (2019)

Berdasarkan hasil uji realibilitas dengan diketahui bahwa nilai cronbach alpha dari masing-masing variabel yang digunakan lebih besar dari 0,6 yang artinya semua variabel yang digunakan pada penelitian realibel.

\section{Hasil Uji Asumsi Klasik}

Uji asumsi klasik yang digunakan dalam penelitian ini meliputi Uji Normalitas, Uji Heterokedasitas, dan Uji Multikoliniearitas. 
Uji Normalitas bertujuan untuk menguji kuesioner, apakah berdistribusi normal atau tidak. Hasil uji normalitas dengan melihat gambar normal plot adalah sebagai berikut:

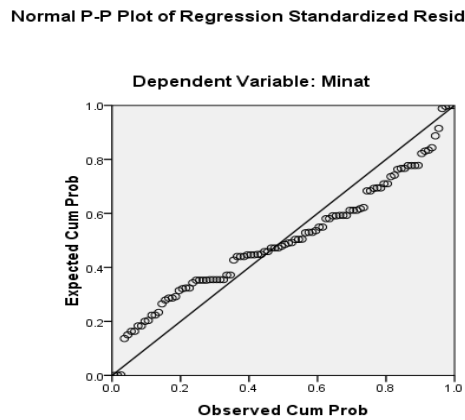

Sumber : Hasil pengolahan data (2019)

Gambar 3. Normal P-P Plot

Gambar 3 menggambarkan Normal P-P Plot menujukkan titik-titik yang mendekati garis diagonal yang berarti secara visual data berdistribusi normal.

Uji Heterokedasitas dalam penelitian ini menggunakan Uji Glejser. Berikut ini hasil Uji Heterokedasitas dengan menggunakan uji Glejser.

Tabel 4. Hasil Uji Glesjer

ANOVA $^{\text {b }}$
\begin{tabular}{|l|l|c|c|c|c|c|}
\hline \multicolumn{2}{|c|}{ Model } & $\begin{array}{c}\text { Sum of } \\
\text { Squares }\end{array}$ & df & $\begin{array}{c}\text { Mean } \\
\text { Square }\end{array}$ & F & Sig. \\
\hline \multirow{2}{*}{1} & Regression & 1.877 & 3 & .626 & 1.346 & $.264^{\mathrm{a}}$ \\
\cline { 2 - 8 } & Residual & 44.639 & 96 & .465 & & \\
\hline \multicolumn{2}{|c|}{ Total } & 46.516 & 99 & & & \\
\hline
\end{tabular}

a. Predictors: (Constant), Kemampuan_Finansial,

Motivasi, Kompetensi

b. Dependent Variable: abres

Sumber : Hasil Pengolahan Data (2019)

Tabel 4 menunjukkan nilai Sig. Uji Glejser adalah sebesar 0,264>0,05. Hal ini menunjukkan bahwa instrumen penelitian bebas dari heterokedasitas.

Uji multikolinearitas dilakukan untuk menguji apakah terjadi linearitas antar variabel bebas dalam penelitian ini, berikut ini hasil uji multikolinearitas penelitian ini:

Tabel 5. Hasil Uji Multikolinearitas

\begin{tabular}{|l|l|c|c|}
\hline \multicolumn{2}{|c|}{ Model } & \multicolumn{2}{c|}{ Collinearity Statistics } \\
\cline { 3 - 4 } & Tolerance & VIF \\
\hline \multirow{4}{*}{1} & (Constant) & & \\
\cline { 2 - 4 } & Motivasi & .265 & 3.776 \\
\cline { 2 - 4 } & Kompetensi & .229 & 4.365 \\
\cline { 2 - 4 } & Kemampuan_Finansial & .232 & 4.302 \\
\hline
\end{tabular}

a. Dependent Variable: Minat

Sumber : Hasil Pengolahan Data (2019)

Berdasarkan hasil uji multikolinearitas pada Tabel 5, diketahui bahwa model penelitian ini lolos uji multikolinearitas karena nilai Tolerance masing-masing variabel lebih dari 0,1 dan nilai VIF kurang dari 10.

3. Model Penelitian

Berikut ini merupakan ringkasan model yang dihasilkan pada penelitian ini.

Tabel 6. Analisis Koefisien Determinasi Model Summary ${ }^{\text {b }}$

\begin{tabular}{|c|c|c|c|c|}
\hline Model & $\mathbf{R}$ & $\begin{array}{c}\text { R } \\
\text { Square }\end{array}$ & $\begin{array}{c}\text { Adjusted } \\
\text { R Square }\end{array}$ & $\begin{array}{c}\text { SE of the } \\
\text { Estimate }\end{array}$ \\
\hline 1 & $.962^{\text {a }}$ & .926 & .924 & .904 \\
\hline a. Predictors: & (Constant), & \multicolumn{2}{c|}{ Kemampuan_Finansial, }
\end{tabular}

Motivasi, Kompetensi

b. Dependent Variable: Minat

Sumber: Data Pengolahan Data (2019)

Berdasarkan analisis koefisien dengan model summary pada Tabel 6 , diketahui bahwa nilai koefisien korelasi $(\mathrm{R})=0,962$ dan nilai koefisien determinasi $(\mathrm{R}$ Square) adalah 0,926 dan nilai $R$ Square setelah disesuaikan (Adjusted $R$ Square) adalah 0,924. Dengan demikian dapat dinyatakan bahwa Minat melanjutkan studi (Y) dapat dijelaskan oleh variabel motivasi, kompetensi dan kemampuan finansial sebesar 92,4\% sedangkan sisanya sebesar $7,6 \%$ dapat dijelaskan oleh faktor lain diluar yang diteliti.

Tabel 7. Analisis Koefisien Persamaan Regresi Linier Berganda

Coefficients $^{\mathrm{a}}$

\begin{tabular}{|l|l|c|c|}
\hline \multicolumn{2}{|c|}{ Model } & \multicolumn{2}{c|}{$\begin{array}{c}\text { Unstandardized } \\
\text { Coefficients }\end{array}$} \\
\cline { 3 - 4 } \multicolumn{2}{|c|}{} & B & Std. Error \\
\hline \multirow{2}{*}{1} & (Constant) & 1.771 & .876 \\
\cline { 2 - 4 } & Motivasi & .378 & .061 \\
\cline { 2 - 4 } & Kompetensi & .320 & .049 \\
\cline { 2 - 4 } & Kemampuan_Finansial & .230 & .043 \\
\hline
\end{tabular}

a. Dependent Variable: Minat

Sumber: Data Pengolahan Data (2019)

Untuk menetapkan model persamaan regresi linier pengaruh motivasi, kompetensi dan kemampuan finansial terhadap minat melakukan penelitian maka perlu dilakukan analisis koofisien regresi linear berganda. Hasilnya adalah sebagai berikut : Konstanta regresi linear berganda yaitu : 1,771, koofisien regresi variable motivasi sebesar 0,378, variabel kompetensi sebesar 0,320 sedangkan kemampuan finansial sebesar 0,230 .

Berdasarkan hasil analisis koefisien regresi pengaruh motivasi, kompetensi dan kemampuan finansial terhadap minat melanjutkan studi pada Dosen di Universitas Tridinanti Palembang. Adapun persamaan regresi linier berganda yang didapat pada penelitian ini adalah :

Minat $=1,771+0,378$ Motivasi $+0,320$ Kompetensi + 0,230 Kemampuan Finansial + Error. 


\section{Uji Hipotesis}

Analisis Regresi Linear Berganda

Analisis uji F (Anova) dilakukan untuk menguji keberartian persamaan regresi linier berganda dan keberartian pengaruh motivasi, kompetensi dan kemampuan finansial secara bersama-sama terhadap minat melanjutkan studi (Y) pada dosen di Universitas Tridinanti Palembang. Hasil analisis dapat dilihat pada Tabel 8. berikut ini :

Tabel 8. Hasil Uji-F (ANOVA)

\section{ANOVA ${ }^{b}$}

\begin{tabular}{|c|c|c|c|c|c|}
\hline Model & $\begin{array}{l}\text { Sum of } \\
\text { Squares }\end{array}$ & $\begin{array}{l}\text { D } \\
\text { f }\end{array}$ & $\begin{array}{l}\text { Mean } \\
\text { Square }\end{array}$ & $\mathbf{F}$ & Sig. \\
\hline 1 Regression & 982.83 & 3 & 327.610 & 400.49 & $.000^{\mathrm{a}}$ \\
\hline Residual & 78.530 & 96 & .818 & & \\
\hline Total & 1061.3 & 99 & & & \\
\hline
\end{tabular}

a. Predictors: (Constant), Kemampuan_Finansial, Motivasi, Kompetensi

b. Dependent Variable: Minat

Sumber: Data Pengolahan Data (2019)

Berdasarkan Tabel 8, pengujian secara bersama-sama (simultan) dengan menggunakan analisis Anova didapat hasil sebagai berikut : nilai F hitung sebesar 400,49 lebih besar dibandingkan $\mathrm{F}$ tabel $(3,090)$. Atau Sig 0,000< 0,05 yang artinya $\mathrm{H}_{0}$ ditolak dan $\mathrm{H}_{\mathrm{a}}$ diterima yang berarti bahwa variabel motivasi $\left(\mathrm{X}_{1}\right)$, kompetensi $\left(\mathrm{X}_{2}\right)$ dan kemampuan finansial $\left(\mathrm{X}_{3}\right)$ secara bersama-sama berpengaruh signifikan terhadap minat melanjutkan studi (Y) pada Dosen di Universitas Tridinanti Palembang.

\section{Analisis Regresi Linear Sederhana (Uji-t)}

Analisis uji t dilakukan untuk melihat bagaimana pengaruh variabel Motivasi $\left(\mathrm{X}_{1}\right)$, Kompetensi $\left(\mathrm{X}_{2}\right)$ dan Kemampuan Finansial $\left(\mathrm{X}_{3}\right)$ terhadap minat melanjutkan studi pada Dosen di Universitas Tridinanti Palembang. Hasil pengujian tersaji pada Tabel 9. berikut ini

Tabel 9. Hasil Uji Regresi Linear Sederhana Coefficients $^{\mathrm{a}}$

\begin{tabular}{|l|l|c|c|c|c|}
\hline \multicolumn{2}{|c|}{ Model } & \multicolumn{2}{|c|}{$\begin{array}{c}\text { Unstandardized } \\
\text { Coefficients }\end{array}$} & \multirow{2}{*}{ t } & \multirow{2}{*}{ Sig. } \\
\cline { 2 - 4 } & B & S.E. & t & .046 \\
\hline \multirow{2}{*}{1} & (Constant) & 1.771 & .876 & 2.023 & .046 \\
\cline { 2 - 4 } & Motivasi & .378 & .061 & 6.159 & .000 \\
\hline & Kompetensi & .320 & .049 & 6.597 & .000 \\
\hline & $\begin{array}{l}\text { Kemampuan_- } \\
\text { Finansial }\end{array}$ & .230 & .043 & 5.309 & .000 \\
\hline
\end{tabular}

a. Dependent Variable: Minat

Sumber: Data Pengolahan Data (2019)

Persamaan regresi linier sederhana ini dapat diartikan dan memiliki makna sebagai berikut : a. Nilai konstanta 1,771, artinya besarnya minat melanjutkan studi pada Dosen di Universitas Tridinanti Palembang tanpa adanya variabel lain seperti motivasi, kompetensi dan kemampuan finansial adalah sebesar 1,771.

b. Nilai koefisien regresi Motivasi $\left(\mathrm{X}_{1}\right)$ 0,378, dan nilai signifikansi sebesar $0,000(<0,05)$ dan nilai t hitung sebesar 6,159 yang artinya bahwa $\mathrm{H}_{0} 1$ ditolak dan $\mathrm{H}_{\mathrm{a}} 1$ diterima. Hal ini berarti bahwa terdapat pengaruh yang signifikan antara motivasi terhadap minat melanjutkan studi pada dosen di Universitas Tridinanti Palembang.

c. Nilai koefisien regresi Kompetensi $\left(\mathrm{X}_{2}\right)$ sebesar 0,320 dan nilai signifikansi sebesar 0,000 $(<0,05)$ dan nilai t-hitung sebesar 6,597 atau lebih besar dibandingkan t-tabel $(3,090)$. Hal ini berarti $\mathrm{H}_{0} 2$ ditolak dan $\mathrm{H}_{\mathrm{a}} 2$ diterima yang artinya bahwa terdapat pengaruh positif yang signifikan antara kompetensi terhadap minat melanjutkan studi pada dosen di Universitas Tridinanti Palembang. Hasil ini membuktikan bahwa Minat melanjutkan studi pada dosen di Universitas Tridinanti Palembang akan meningkat secara signifikan sebesar 0,320 point jika terjadi peningkatan sebesar 1 point pada variabel kompetensi.

d. Nilai koefisien regresi Kemampuan Finansial $\left(\mathrm{X}_{3}\right)$ sebesar 0,230 dan nilai signifikansi sebesar 0,000 $(<0,05)$ dan nilai t-hitung sebesar 5,309 atau lebih besar dibandingkan t-tabel $(3,090)$. Hal ini berarti $\mathrm{H}_{0} 3$ ditolak dan $\mathrm{H}_{\mathrm{a}} 3$ diterima yang artinya bahwa terdapat pengaruh positif yang signifikan antara kemampuan finansial terhadap minat dosen di Universitas Tridinanti Palembang untuk melanjutkan studi. Hasil ini membuktikan bahwa Minat melanjutkan studi pada dosen di Universitas Tridinanti Palembang akan meningkat secara signifikan sebesar 0,230 point $(23 \%)$ jika terdapat peningkatan sebesar 1 point pada variabel kemampuan finansial.

C. Analisis Hasil Penelitian

1. Pengaruh Motivasi Terhadap Minat Melanjutkan Studi Pada Dosen di Universitas Tridinanti Palembang

Motivasi melanjutkan studi adalah dorongan yang muncul dalam diri ataupun dari luar diri seseorang yang membangkitkan kemauan, semangat serta ketekunan untuk melanjutkan studinya ke jenjang yang lebih tinggi dalam rangka pencapaian tujuan tertentu.

Berdasarkan hasil Uji t didapat signifikansi motivasi sebesar 0,000. Nilai 0,000 ini $<0,05$ dan nilai t-hitung sebesar 6,159 atau lebih besar dibandingkan t-tabel $(1,983)$ dengan nilai koofisien regresi sebesar 0,378 . Hal ini berarti $\mathrm{H}_{0} 1$ ditolak dan $\mathrm{H} 1$ diterima yang artinya terdapat pengaruh positif yang signifikan antara motivasi terhadap minat melanjutkan studi pada dosen di Universitas Tridinanti Palembang. Hal ini sejalan dengan hasil uji $\mathrm{F}$ dimana didapat hasil bahwa secara bersamasama (simultan) motivasi berpengaruh signifikan terhadap minat melanjutkan studi pada dosen di 
Universitas Tridinanti Palembang.

Hasil ini mendukung hasil penelitian Seto (2017) dan Nurhayani (2012) yang menyatakan bahwa salah satu faktor yang mempengaruhi minat adalah motivasi pribadi itu sendiri, baik motivasi sosial, karir maupun ekonomi.

Hasil penelitian ini juga menemukan bahwa sebagian besar dosen yang menjadi responden memiliki motivasi yang tinggi untuk melanjutkan studi ke jenjang yang lebih tinggi terutama untuk dosen-dosen yang berusia dibawah 40 tahun. Motivasi ini sebagian besar dipengaruhi oleh lingkungan sosial yaitu rekan-rekan dosen lainnya yang saat ini sedang melanjutkan studi doktor. Tercatat pada tahun 2019 terdapat 11 orang dosen di Universitas Tridinanti yang sedang menempuh studi lanjut. Namun besarnya motivasi ini belum cukup untuk merealisasikan minat dosen untuk melanjutkan studi karena keterbatasan pada beberapa faktor lainnya seperti finansial.

2. Pengaruh Kompetensi Terhadap Minat Melanjutkan Studi Pada Dosen di Universitas Tridinanti Palembang

Kompetensi adalah karakteristik yang mendasari seorang dosen yang berkaitan dengan efektifitas kinerja individu dalam melaksanakan berbagai pekerjaannya. Kompetensi merupakan salah satu faktor yang dianggap harus dimiliki oleh setiap dosen yang ingin meningkatkan jenjang pendidikan maupun mengembangkan karirnya.

Berdasarkan hasil Uji $\mathrm{t}$ didapat nilai signifikansi kompetensi sebesar 0,000. Nilai 0,000 ini < 0,05 dengan nilai koofisien regresi sebesar 0,320 . Hal ini berarti $\mathrm{H}_{0} 2$ ditolak dan $\mathrm{H} 2$ diterima yang artinya terdapat pengaruh positif yang signifikan antara kompetensi terhadap minat melanjutkan studi pada dosen di Universitas Tridinanti Palembang. Hal ini sejalan dengan hasil uji $\mathrm{F}$ dimana didapat hasil bahwa secara bersama-sama (simultan) kompetensi berpengaruh secara signifikan terhadap minat melanjutkan studi pada dosen di Universitas Tridinanti Palembang.

Hasil ini sejalan dengan hasil kajian Kusuma (2009) yang menyatakan meskipun bukan merupakan variabel yang dominan akan tetapi kompetensi secara signifikan mempengaruhi minat seseorang.

Selain ini hasil observasi penelitian menunjukkan bahwa kompetensi dosen di Universitas Tridinanti Palembang cukup baik dan dapat mendukung minat untuk melanjutkan studi baik dari segi linearitas maupun keilmuannya, namun kompetensi yang cukup baik ini kurang didukung oleh rasa percaya diri, hal ini terlihat dari masih minimnya dosen di Universitas Tridinanti Palembang yang memiliki kemauan dan berani untuk mencari beasiswa studi lanjut, baik dalam maupun luar negeri.

3. Pengaruh Kemampuan Finansial Terhadap Minat Melanjutkan Studi Pada Dosen di Universitas Tridinanti Palembang
Kemampuan finansial pada penelitian ini dapat diartikan sebagai kemampuan seorang dosen untuk membiayai studi lanjutnya dalam upaya mengaplikasikan minatnya.

Berdasarkan hasil uji $\mathrm{t}$ didapat nilai signifikansi kemampuan finansial sebesar 0,000. Nilai 0,000 ini < 0,5 berarti H3 diterima yang artinya bahwa kemampuan finansial berpengaruh terhadap minat melanjutkan studi pada dosen di Universitas Tridinanti Palembang. Hasil ini sejalan dengan hasil uji $\mathrm{F}$ dimana didapat hasil bahwa secara bersama-sama (simultan) kemampuan finansial berpengaruh signifikan terhadap minat melanjutkan studi pada dosen di Universitas Tridinanti Palembang.

Hasil ini mendukung hasil penelitian Azizah (2015) yang menemukan bahwa kemampuan finansial secara simultan berpengaruh terhadap minat. Hasil penelitian juga menemukan bahwa keterbatasan finansial dimana pendapatan mayoritas dosen yang bersumber dari gaji dan tunjangan lainnya seperti sertifikasi dosen masih dinilai belum memadai untuk mencover (menutupi) biaya studi lanjut.

\section{Kesimpulan}

Berdasarkan analisis yang telah dilakukan, maka didapat beberapa kesimpulan pada penelitian ini:

1. Secara simultan motivasi, kompetensi dan kemampuan finansial berpengaruh signifikan terhadap minat melanjutkan studi pada dosen di Universitas Tridinanti Palembang dengan nilai Signifikansi 0,000.

2. Motivasi secara parsial berpengaruh terhadap minat melanjutkan studi pada dosen di Universitas Tridinanti Palembang dengan nilai Signifikansi 0,000 . Besarnya pengaruh motivasi terhadap minat melanjutkan studi pada dosen di Universitas Tridinanti Palembang sebesar 37,8\%.

3. Kompetensi secara parsial berpengaruh terhadap minat melanjutkan studi pada dosen di Universitas Tridinanti Palembang dengan nilai Signifikansi 0,000. Besarnya pengaruh kompetensi terhadap minat melanjutkan studi pada dosen di Universitas Tridinanti Palembang sebesar 32,0\%.

4. Kemampuan Finansial secara parsial berpengaruh terhadap minat melanjutkan studi pada dosen di Universitas Tridinanti Palembang dengan nilai Signifikansi 0,000. Besarnya pengaruh kemampuan finansial terhadap minat melanjutkan studi pada dosen di Universitas Tridinanti Palembang sebesar $23,0 \%$.

\section{Daftar Pustaka}

Azizah, N. A., 2015, Pengaruh Marketing Mix dan Kemampuan Finansial Terhadap Minat Investasi Reksadana Syariah: Studi pada UIN Jakata dan Tazkia Bogor. E-Journal UIN Syarif Hidayatullah, Jakarta http://repository.uinjkt.ac.id/dspace/handle/123456 $\underline{789 / 30736}$ 
Bangun, Wilson, 2018, Manajemen Sumber Daya Manusia, Erlangga, Bandung

Crow and Crow., 2003, An Outline of Psycology, Surabaya, PT Bina Ilmu.

Daft, R. L., 2011, Manajemen Era Baru, Buku 2 Edisi 9, Erlangga, Bandung.

Kusuma, A. R., (2009), Pengaruh Kualitas Pelayanan, Kompetensi Tenaga Penjualan, Dan Citra Perusahaan Terhadap Minat Beli Ulang (Studi pada PT. Ratna Intan Kusuma di Semarang). Doctoral dissertation, Universitas Diponegoro.

Ghozali, Imam., 2005, Aplikasi Analisis Multivariate Dengan Program SPSS Edisi Ketiga, Semarang, Badan Penerbit Universitas Diponegoro.

Ismalil, M., \& Lestari, E., 2012, Pengaruh Motivasi Terhadap Minat Mahasiswa Akuntansi untuk Mengikuti Pendidikan Profesi Akuntansi (PPAk) di Perguruan Tinggi Sumatera Utara. Jurnal Keuangan \& Bisnis Program Studi Magister Manajemen Sekolah Tinggi Ilmu Ekonomi Harapan, 4(2), 160-171.

Notoatmodjo, Soekidjo., 2009, Pengembangan Sumber Daya Manusia, Jakarta, Rineka Cipta.

Nurhayani, U., 2012, Pengaruh Motivasi Terhadap Minat Mahasiswa Akuntansi untuk Mengikuti Pendidikan Profesi Akuntansi (PPAk) (Studi Empiris pada Perguruan Tinggi Swasta Medan). Jurnal Mediasi, 4(01), 59-67.

Seto, A. A., 2017, Regulasi dan Motivasi Terhadap Minat Menjadi Dosen Pada Perguruan Tinggi Swasta di Kota Palembang, In Prosiding Seminar Nasional Darmajaya, 1(1), 165-175.

Spencer., 2009, An Overview of Compentence, Englewood Cliffs, New Jersey, Prentice Hall.

Sugiyono., 2010, Metode Penelitian Kuantitatif, Kualitatif, dan R\&D, Bandung, CV Alfabeta. 